\title{
LIPASE PRODUCING THERMOPHILIC BACTERIA ISOLATION AND CHARACTERIZATION FROM HOT SPRINGS OF CENTRAL INDIA
}

\author{
SHREYANSH PARSAI, KAMLESH CHOURE*, ARPIT SRIVASTAVA, PIYUSH KANT RAI, VIVEK AGNIHOTRI \\ and SOURABH SINGH GOUR
}

Department of Biotechnology, A.K.S. University, Satna (M.P.)

\begin{abstract}
Hot springs considered being a unique domain of novel extremophiles which are useful for production of industrially important enzymes, to understand the metabolic reactions and for producing other biotechnological products. The aim of the present research was isolation and characterization of thermophilic bacteria containing potential to produce extracellular lipase enzyme from the geothermal springs located in central India. Water is used as test sample in order to obtain thermophilic bacteria. 10 thermophilic bacteria were isolated from the water samples and subjected to screening for the potential of producing lipase enzyme of which 8 isolates are potential producer of extracellular lipase. Two isolates with higher zone of clearance around them were selected for the further investigation. Morphological, biochemical and molecular identification by $16 \mathrm{~S}$ rRNA sequencing of these isolates (BAC23 and BAC26) could be identified as Bacillus haynesii and Bacillus clausii. The lipolytic activity of these isolates was recorded stable at optimum temperature range of $45^{\circ} \mathrm{C}-60^{\circ} \mathrm{C}$ with alkaline $\mathrm{pH}$ at $9.0-9.4$ and at $0.5-1.0 \mathrm{M}$ salinity. Capability to produce extracellular thermostable lipase at high temperature and $\mathrm{pH}$, these strains of Bacillus spp. can be presented as promising contender for modern industrial applications.
\end{abstract}

Keywords : Bacillus haynesii, Bacillus clausii, Hot springs, Thermophilic bacteria, Thermostable lipase.

\section{INTRODUCTION}

A wide scope of organism's living spaces and be a basic aspect of all condition extending from moderate to brutal conditions to live like high temperature water springs, aqueous vents, salterns and other such situations with outrageous conditions, where common life conditions are not seen. Thermophiles are the life forms adjusted to develop ideally at high temperatures going from $55^{\circ} \mathrm{C}-121^{\circ} \mathrm{C}$ (Kumar et al., 2013). Worldwide, concentrates on microbial communities in hot springs have essentially focused on natural surroundings at low rises like Yellowstone National Park (Mitchell,2009), Kamchatka in Russia, Iceland (Reigstad et al.,2010), Indonesia (Aditiawati et al.,2009) and Tunisia (Sayeh et al., 2010). India is the home to a few geothermal hot springs, particularly the Himalayan Geothermal Belt (HGB) which contains near 150 warm springs.

Microbial communities present in such environments comprise important hotspots for different biotechnological ap plications (Satyanarayana et al.,2005 and Sayeh et al.,2010). Thermophilic microorganisms have indicated colossal potential in biotechnology due to their capacity to deliver special thermostable enzymes and proteins with high stability and activity (Demirijan,2001 and Tehei \& Zaccai,2005). One of commonly used enzyme in industries is the Taq DNA polymerase, which is a catalyst isolated from the hot springs bacterium Thermus aquaticus (Chien et al.,1976 and Podar \& Reysenbach,2006). Thermostable enzymes from these microorganisms such as proteases, amylases, lipases cellulases, xylanases, pectinases, gelatinases, DNAses (Verma et al., 2014) are in extraordinary interest as they are not typically denatured at high temperature, however are somewhat more dynamic at raised temperature (Adams \& Kelly,1998 and Zeikus et al.,1998).
Among them Lipases are a flexible group of catalysts and regularly express different activities like phospholipase, isophospholipase, cholesterol esterase, chitinase, amidase and other esterase kind of activity (Svendsen,2000). Importantly they are used in paper, food, pharmaceutical, leather, textile, detergent and cosmetic industries. A few thermophilic lipases have been purged and portrayed from Thermophilic Bacillus sp. (Sharma et al.,2002), Bacillus thermoleovorans (Lee et al.,1999 and Markossian et al., 2000), Bacillus stearothermophilus (Sinchaikul et al.,2001), Bacillus circulans (Kademi et al.,2000). Hence many more novel and useful genetic pool of thermophilic microbes is expected to be discovered from the unexplored hot springs of central India. These extremophiles are having biotechnological importance as they produce industrial enzymes which function in extreme environments (extremozymes). Therefore, the goal of this investigation is to isolate thermophilic bacteria from this region and screen them for the high potential of producing the industrial product such as enzyme that are able to tolerate high temperature.

\section{MATERIAL AND METHODS}

\section{Sample collection :}

Water samples in different season were aseptically collected from Choti Anhoni Pachmari (CAP) Hoshangabad and Badi anhoni in Chindwada district (BAC), the two selected hot spring areas of Madhya Pradesh for this research. The sample is withdrawn from the source of hot water in an air tight glass vials and these vials placed in a thermo flask containing a temperature more than that of source, to maintain the temperature as well as avoidance of damage of samples during transportation and used for the investigation of physical parameters (Anderson et al.,2006). 
Isolation of Bacteria and conventional methodology for identification : The sample were serially diluted up to $10^{-9}$ and grown in Erlenmeyer flask containing Luria Bertani (Himedia, Mumbai) broth of different $\mathrm{pH}$, and incubated at $50^{\circ} \mathrm{C}$ for 24 hours. After growth $100 \mu \mathrm{l}$ from each flask is than spreaded on NAM (Himedia, Mumbai) plates and incubated again at $50^{\circ} \mathrm{C}$ for 24 hours. Various bacterial colonies with different morphologies are selected and subjected to subculturing in order to obtain pure culture in NA plates. Morphological characterization of each pure culture was carried out by examining colour, size, colony morphology gram staining as described by (Kristjansson et al.,1992). Biochemical characterization test such as catalase, oxidase, citrate, sugar utilization, motility, and urease was applied by using the method described previously by (Aneza,2003). Temperature effects, $\mathrm{pH}$ and salt concentration effects on all the isolates were carried out by growing at different temperature, $\mathrm{pH}$ and $\mathrm{NaCl}$ concentration at $0.5-2.0 \mathrm{M}$ for $24-48$ hours.

\section{Screening for Enzyme producing potential and Molecular identification}

Lipase activity : Lipolytic activity was detected by using tributyrin agar (peptone 5 grams, yeast extract 3 grams, agar 15 grams and tributyrin $10 \mathrm{ml}$ ) by streaking single line of the culture followed by the incubation of $24 \mathrm{hrs}$ at $55^{\circ} \mathrm{C}$ (Rollof et al.,1987). The $\mathrm{pH}$ of the media was adjusted to alkaline at 8.0. For the detection of lipase activity presence of halo clear zone around the inocula indicate lipase activity.

16s rDNA Amplification : The DNA was isolated from the bacteria by using the method described by Sambrook and Russel in 2001. In the present study PCR amplification of $16 \mathrm{~s}$ rDNA was achieved by using PCR reaction mixture with universal primers $27 \mathrm{~F}$ and $1492 \mathrm{R}$ (eurofins Genomics Luxembourg). The final reaction mixture is $50 \mu \mathrm{l}$ for $16 \mathrm{~S}$ rRNA gene amplification with universal primer $1492 \mathrm{R}$ ( 5 'CGGTTACCTTGTTACGACTT3') and $27 \mathrm{~F}$
(5'AGAGTTTGATCMTGGCTCAG3'). The composition of the reaction mixture used is $5 \mu 1$ of 10x Taq Buffer ( $\mathrm{pH} 9.1$ at $20^{\circ} \mathrm{C}$ ), $2 \mu 1-50 \mathrm{mM} \mathrm{MgCl}_{2}, 5 \mu \mathrm{l}$ of $2 \mathrm{mM}$ dNTPs, $1 \mu \mathrm{l}$ of Taq polymerase $3 \mu \mathrm{l}$ of $27 \mathrm{~F}$ primer and $5 \mu \mathrm{l}$ of $1492 \mathrm{R}$ primer is added along with the $3 \mu \mathrm{l}$ of template DNA at the end and the final volume is brought up to $50 \mu \mathrm{l}$ (Heuer et al.,1997). The PCR reaction were performed by using Applied Biosystems Veriti ${ }^{\text {TM }}$ 96-Well Thermal Cycler under the following thermocycling condition set as initial denaturation at $950 \mathrm{C}$ for 2 minutes followed by 30 cycles of denaturation at $95^{\circ} \mathrm{C}$ for 30 seconds, annealing at $52^{\circ} \mathrm{C}$ for 30 seconds and elongation at $72^{\circ} \mathrm{C}$ for 2 minutes followed by extension at $72^{\circ} \mathrm{C}$ for 8 minutes. The band patters were visualized on automated transilluminator Gel doc instrument (Azure Biosystems, Inc.).

Sequencing of 16s rDNA amplicons and phylogenetic analysis : The amplified product obtained by $16 \mathrm{~S}$ rDNA amplification was subjected for purification by PCR cleanup Kit and the method is followed as described by the manufacturer (Gentix Biotech). 16S rDNA PCR amplicon is purified, diluted for sequencing as $100 \mathrm{ng} / 2 \mu \mathrm{l}$ and sequenced for both DNA strands using the same primer as used in 16s rDNA amplification i.e. 27F and 1492R (Genombio Technologies Pvt. Ltd., Pune). The sequence obtained after sequencing were used for the analysis using similarity search by online web server blastn (nucleotide blast) for $16 \mathrm{~S}$ ribosomal RNA available at NCBI. The sequences are than used for multiple sequence alignment by another web server ClustalW (Thompson et al.,1994). Finally, phylogenetic tree was constructed using MEGAX 10.1 computer programme by using Maximum Parsimony method as mentioned by Tamura et al. (2001).

\section{RESULTS AND DISCUSSION}

In the present study the presence of thermophilic bacteria belongs to genus Bacillus were investigated from the samples isolated from the hot springs of Madhya Pradesh. The

Table. 1 Physiological parameters of water samples.

\begin{tabular}{lccccccc}
\hline Sample & $\begin{array}{c}\text { Electrical } \\
\text { conductivity } \mathbf{~ m s}\end{array}$ & $\begin{array}{c}\text { Turbidity } \\
\text { NTU }\end{array}$ & $\begin{array}{c}\text { DO } \\
\mathbf{m g} / \mathbf{l}\end{array}$ & $\begin{array}{c}\text { B OD } \\
\boldsymbol{\mu g} / \mathbf{m l}\end{array}$ & $\begin{array}{c}\text { COD } \\
\mathbf{m g} / \mathbf{l}\end{array}$ & $\begin{array}{c}\text { TDS } \\
\text { (ppm) }\end{array}$ & $\begin{array}{c}\text { NaCl } \\
\text { conc. }\end{array}$ \\
\hline Site 1 Water & 7.91 & 7.12 & 9 & 187 & 389 & 412 & $1.6 \%$ \\
Site 2 Water & 827 & 5.96 & 17.1 & 120 & 1144 & 376 & $2.4 \%$ \\
\hline
\end{tabular}

Table. 2 Morphological characteristics of isolated bacterial samples of hot springs.

\begin{tabular}{lccccccc}
\hline Strain & \multicolumn{7}{c}{ Morphological characteristics } \\
\cline { 2 - 7 } & Size $(\mathbf{m m})$ & Color & Gram & Shape (cells) & Spore & Motility & Shape \\
\hline CAP1 & 2 & Creamy white & $+\mathrm{ve}$ & Rod & $+\mathrm{ve}$ & Motile & circular \\
CAP2 & 2.8 & Yellowish & $-\mathrm{ve}$ & Rod & $+\mathrm{ve}$ & Motile & Irregular \\
CAP3 & 2 & Creamy yellow & $-\mathrm{ve}$ & Rod & $+\mathrm{ve}$ & Motile & Irregular \\
CAP4 & 1.6 & & Cocci & $+\mathrm{ve}$ & Motile & Irregular \\
BAC22 & & Yellowish & $-\mathrm{ve}$ & & $+\mathrm{ve}$ & Non motile & circular \\
BAC23 & 0.9 & Creamy white & $+\mathrm{ve}$ & Rod & $+\mathrm{ve}$ & Motile & rhizoid \\
BAC24 & 2 & Creamy yellow & $+\mathrm{ve}$ & Cocci & $+\mathrm{ve}$ & Non Motile & rhizoid \\
BAC25 & 1.7 & Yellowish & & Cocci & $+\mathrm{ve}$ & Motile & circular \\
BAC26 & $3-4$ & Creamy white, circular & $+\mathrm{ve}$ & Rod & $+\mathrm{ve}$ & Motile & Circular \\
BAC27 & 2 & Yellowish & $+\mathrm{ve}$ & Cocci & $+\mathrm{ve}$ & Motile & re
\end{tabular}


temperature of surface water is different and it gradually increases when the thermometer is dipped deeper in the kund (Source of hot spring). Temperature and $\mathrm{pH}$ of both the source was $55^{\circ} \mathrm{C} \mathrm{pH} \mathrm{8.0-8.5} \mathrm{for} \mathrm{CAP} \mathrm{and} 55-68^{\circ} \mathrm{C}$ with $\mathrm{pH} 9.0$ for BAC. Physio-chemical parameter was measured by HANNA instruments for measuring the listed parameters Table.1. Among the two water sample collected from both the sites 10 pure isolates were obtained and assigned the codes viz. CAP1, CAP2, CAP3, CAP4, BAC22, BAC23, BAC24, BAC25, BAC26, BAC27. Morphological characterization i.e colony shape, size, margin, form, elevation, surface and gram staining of the all isolates were listed in (Table.2). All the strain shown positive growth against different range of temperature from $45-65^{\circ} \mathrm{C}$ except few which shows negative results and growth beyond $65^{\circ} \mathrm{C}$ is not observed in any strains (Table.3). Likewise, maximum growth was observed at $\mathrm{pH}$ ranges from 8-10 for all the strains (Table.4). Isolates CAP1, CAP2, CAP3, CAP4, BAC22, BAC23, BAC24, BAC25, BAC26, $\mathrm{BAC} 27$ are positive for catalase, oxidase, citrate, sugar utilization and citrate except few which shows negative results (Table.5)

Nearly all the strains are able to produce halo zone of clearance around the inocula except CAP4, among which two strain i.e. $\mathrm{BAC} 23$ and $\mathrm{BAC} 26$ shows the highest zone of clearance around the single line streaked inocula, indicates the high potential of producing thermostable lipase and these two strains are used for sequencing. These strains can able to grow at optimum temperature of about $55-65^{\circ} \mathrm{C}$ and can toler-

Table. 3 Bacterial isolates growth at various temperature range.

\begin{tabular}{lcccccc}
\hline Strain & \multicolumn{7}{c}{ Temperature in ${ }^{\circ} \mathbf{C}$} \\
\cline { 2 - 6 } & $\mathbf{4 5}$ & $\mathbf{5 0}$ & $\mathbf{5 5}$ & $\mathbf{6 0}$ & $\mathbf{6 5}$ & $\mathbf{7 0}$ \\
\hline CAP1 & + & - & + & + & - & - \\
CAP2 & + & - & + & + & - & - \\
CAP3 & - & + & + & + & + & + \\
CAP4 & + & + & + & + & + & + \\
BAC22 & - & + & + & + & - & - \\
BAC23 & + & + & + & + & + & + \\
BAC24 & - & + & + & + & + & + \\
BAC25 & + & + & + & + & + & - \\
BAC26 & - & + & + & + & + & + \\
BAC27 & + & + & + & + & + & - \\
\hline$+=$ Presence of activity, - = Absence of activity. & & &
\end{tabular}

Table. 4 Bacterial isolates growth at various $\mathrm{pH}$ range.

\begin{tabular}{lcccccc}
\hline Strain & \multicolumn{7}{c}{$\mathbf{p H}$} \\
\cline { 2 - 6 } & $\mathbf{6}$ & $\mathbf{8}$ & $\mathbf{9}$ & $\mathbf{1 0}$ & $\mathbf{1 2}$ & $\mathbf{1 4}$ \\
\hline CAP1 & - & - & + & + & - & - \\
CAP2 & - & - & + & + & - & - \\
CAP3 & - & + & + & + & + & - \\
CAP4 & - & + & + & + & - & - \\
BAC22 & - & + & + & + & - & - \\
BAC23 & + & + & + & + & + & - \\
BAC24 & - & + & + & + & - & - \\
BAC25 & + & + & + & + & - & - \\
BAC26 & - & + & + & + & - & - \\
BAC27 & + & + & + & + & - & - \\
\hline$+=$ Presence of activity, - = Absence of activity. & & &
\end{tabular}

ate high $\mathrm{pH}$ of about 9-10. Both these strains are capable of fermenting different sugars such as maltose, dextrose, raffinose, arabinose, ribose, glucose, sucrose and fructose while producing the acids and gas as the end products. Genotypic and phenotypic identification of the thermophilic strains was carried out previously in many geothermal areas including India (Sharma et al.,2008), Greece (Sievert et al.,2000), Italy (Maugeri et al.,2001), Turkey (Gul-Guven et al.,2008), Bulgaria (Derekova et al.,2008) and China (Lau et al.,2009).

16S rDNA amplification by using the universal forward and reverse primer i.e. $1492 \mathrm{R}$ and $27 \mathrm{~F}$ of these two isolates produce amplified products as PCR bands and these were subjected to electrophoresis which reveals the size of the product is between $1500 \mathrm{bp}$ by using reference ladder DNA of $500 \mathrm{bp}$. Sequencing of these two isolates produce $781 \mathrm{bp}$ for BAC 23 and 784 bp for BAC26 with $50-60 \% \mathrm{G}+\mathrm{C}$ content. Both strains are used for Insilico study in order to obtain highest similarity using online web server nucleotide blastn based on the BLAST alignment and set as rRNA/ITS database for $16 \mathrm{~S}$ ribosomal RNA sequences. These isolates were found belong to genus Bacillus clausii (DSM 8716) and Bacillus haynesii (NRRL B-41327) for BAC 23 and BAC26 with 98\% and $97 \%$ similarity respectively and were subjected to multiple sequence alignment by using online server clustal Khalil (2011) identified Bacillus sp., Brevibacillus borstelenesis by using molecular characterization from the hot springs in Saudi Arabia and reported that these species are potential producers of thermostable lipases and can be active at temperature range of $55^{\circ} \mathrm{C}-65^{\circ} \mathrm{C}$ with alkaline $\mathrm{pH}$ of about 8.5-9.5.

Determination of the molecular community by phylogenetic analysis of $16 \mathrm{~S}$ rRNA gene sequence indicate that all the phylotypes are associated with Firmicutes retrieved from enrichment culture. Phylogenetic tree was constructed using maximum likelihood parsimony (Felstein,1996) with computer programme MEGAX 10.1. The phylogenetic analysis of the $16 \mathrm{~S}$ rRNA gene sequences of these two thermophilic isolates reveals the $98 \%$ homology Bacillus clausii and Bacillus haynesii (Figs.1\&2). It was revealed that Bacillus isolates BAC23 be put under the species Calusii with $98 \%$ homology and about $97 \%$ homologues of rhizospharae. While Bacillus isolate BAC26 reveals 96\% homology with

Table. 5 Biochemical characterization and lipase acivity of bacterial isolates.

\begin{tabular}{lcccccc}
\hline Strain & \multicolumn{7}{c}{ Biochemical test } \\
\cline { 2 - 7 } & Catalse & Oxidase & Citrate & Urease & Sugar & Lipase \\
\hline CAP1 & + & + & + & + & + & + \\
CAP2 & + & + & + & + & + & + \\
CAP3 & + & + & + & + & + & + \\
CAP4 & + & - & + & - & + & - \\
BAC22 & + & - & + & - & + & + \\
BAC23 & + & + & + & + & + & + \\
BAC24 & + & - & - & + & + & + \\
BAC25 & + & + & - & - & + & + \\
BAC26 & + & + & + & + & + & + \\
BAC27 & + & + & + & + & + & + \\
\hline$+=$ Presence of activity, - = Absence of activity.
\end{tabular}




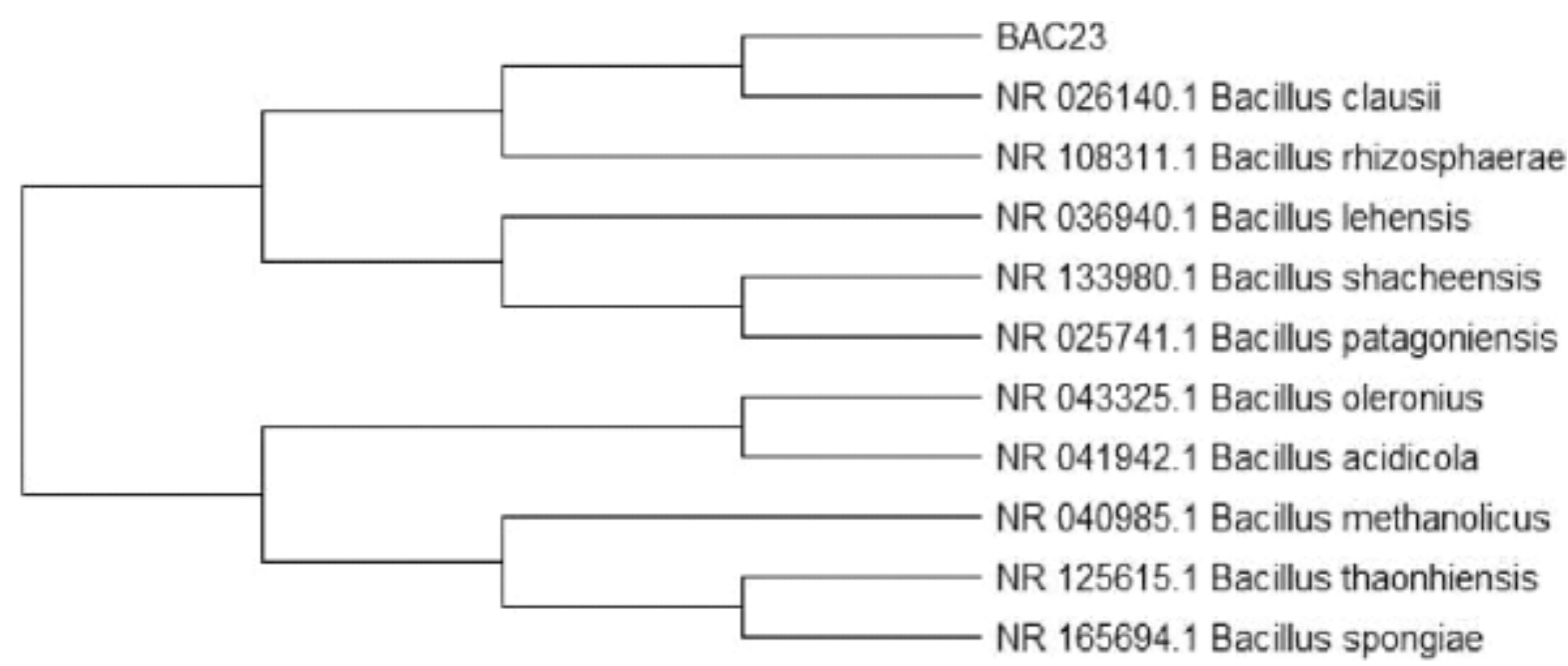

Fig. 1 Phylogenetic relationship of isolate BAC23 showing with the analyzed sequences by maximum likelihood method based on 16S rRNA gene sequence

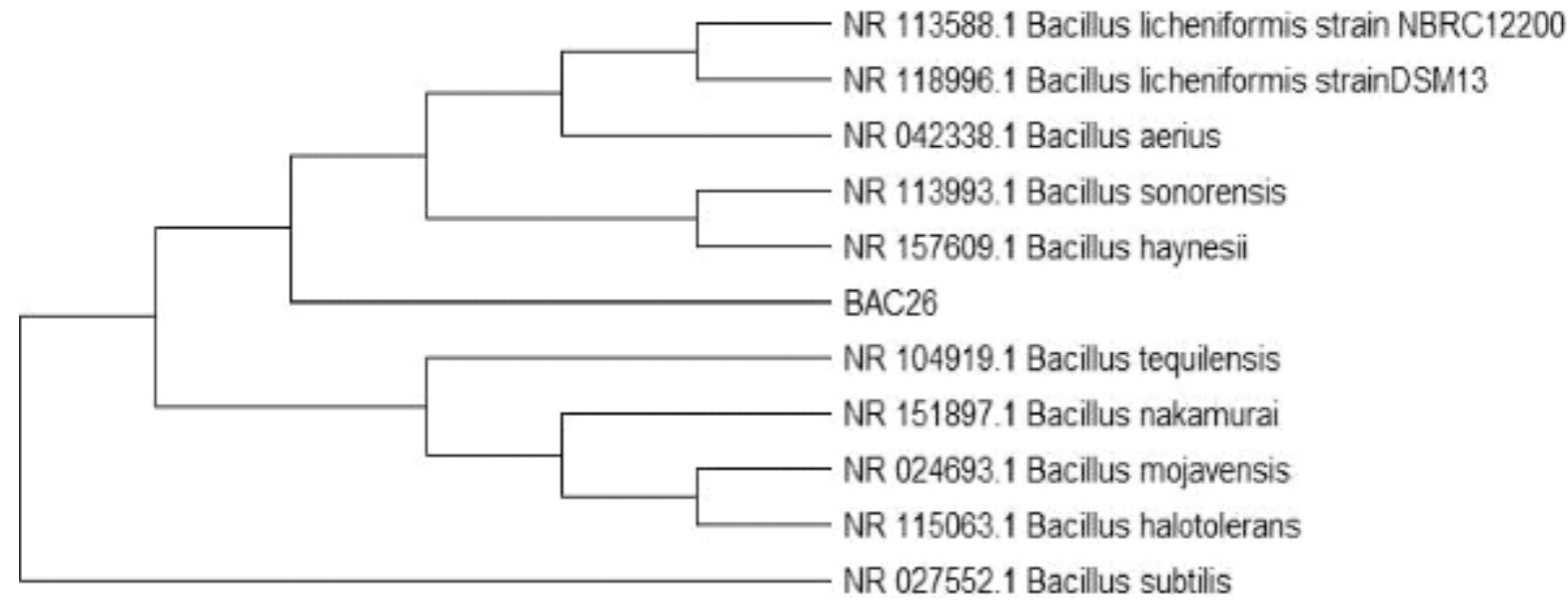

Fig. 2 Phylogenetic relationship of isolate BAC26 showing with the analysed sequences by maximum likelihood method based on $16 \mathrm{~S}$ rRNA gene sequence

Haynesii and 94-95\% homology with other species of Bacillus sonorensis, B.aerius, B.licheniformis of different strain. Ugras (2017) in his study on the hot spring area of Hayran thermal springs in Giresun identified Bacillus Licheniformis and Bacillus subtilis on the basis of biochemical and molecular characterization by $16 \mathrm{~S}$ rDNA sequencing and shows the maximum activity of the lipases enzyme is at temperature of $90^{\circ} \mathrm{C}$ at $9 \mathrm{pH}$.

The aim of this study was to isolate thermophilic bacteria from the hot springs of Madhya Pradesh and has potential to produce thermostable enzyme lipase. We have isolated
10 thermophilic bacteria and screen for the potential of extracellular lipase production. Further isolates were used for the biochemical and morphological characterization. Two isolates having the highest turbid halo zone of clearance around the inocula is used for the molecular characterization. Analysis of molecular characterization reveals the isolates belong to Bacillus clausii and Bacillus haynesii, that can be able to grow at the temperature of $60^{\circ} \mathrm{C}$ and can tolerate high $\mathrm{pH}$ of about 9.0. Characteristics of both the strains such as thermo stability, alkalophilicity and potential of producing thermostable lipase could be used as a promising candidate in industries which uses lipases.

\section{REFERENCES}


Aditiawati, P.; Yohandini, H.; Madayanti, F. and Akhmaloka (2009). Microbial diversity of acidic hot spring (Kawah hujan B) in geothermal field of Kamojang area, West Java-Indonesia. Open Microbiology Journal, 3 : 58-66.

Anderson, N. John; Ryves, B. David; Battarbee, W. Richard; Juggins, Stephen and Fritz, C. Sheyilyn (2006). Physical and chemical predictors of diatom dissolution in freshwater and saline lake sediments in North America and West Greenland. Limnology and Oceanography, 51(3) : 1355-1368

Aneja, K. R. (2003). Experiments in microbiology, plant pathology and biotechnology : $4^{\text {th }}$ edn. New Age International Limited, New Delhi. pp. $245-275$.

Chien, A.; Edgar, D. B. and Trela, J. M. (1976). Deoxyribonucleic acid polymerase from the extreme thermophile Thermus aquaticus. Journal of Bacteriology, $127:$ 1550-1557.

Demirijan, D.; Moris-Varas, F. and Cassidy, C. (2001). Enzymes from extremophiles. Current Opinion in Chemical Biology, 5 : 144-151

Derekova, A.; Mandeva, R. and Kambourova, M. (2008). Phylogenetic diversity of thermophilic carbohydrate degrading Bacilli from Bulgarian hot springs. World Journal of Microbiology and Biotechnology, 24: 1697-1702.

Felstein, J. (1996). Inferring phylogeny from protein sequences by parsimony, distance and likelihood methods. Mtds. Enzymol., 266: 368382 .

Gul-Guven, R.; Guven, K.; Poli, A. and Nicolaus, B. (2008). Anoxybacillus kamchatkensis subsp. saccharedens a nov., a thermophilic bacterium isolated from a hot spring in Batman. Journal of General and Applied Microbiology, 54 : 327-334.

Heuer, H.; Krsek, M.; Baker, P.; Smalla, K. and Wellington, E. M. (1997). Analysis of actinomycete communities by specific amplification of genes encoding 16S rRNA and gel-electrophoretic separation in denaturing gradients. Appl. Environ. Microbiol., 63(8) : $3233-3241$.

Kademi, A.; Abdelkader, N.; Fakhreddine, L. and Baratti, J. C. (2000). Characterization of a New Thermostable Esterase from the moderate Thermophilic Bacterium Bacillus Circulans. Journal of Molecular Catalyzis B : Enzymatic, 10 : 395-401.

Khalil, A. (2011). Isolation and characterization of three thermophilic bacterial strains (lipase, cellulose and amylase producers) from hot springs in Saudi Arabia. African Journal of Biotechnology, 10: 8834-8839.

Kristjansson, J. K. and Stetter, K. O. (1992). Thermophilic bacteria. In : Thermophilic Bacteria (ed. Kristjansson, J. K.). CRC Press, Boca Raton, Ann Arbor, London, pp. 1-18.

Kumar, N.; Singh, A. and Sharma, P. (2013). To study the physico-chemical properties and bacteriological examination of hot spring water from Vashisht region in distt. Kullu of H.P. International Research Journal of Environment Sciences, 2 : 28-31.

Kumar, Sudhir; Tamura, Koichiro; Ingrid B. Jakobsen and Masatoshi Nei, MEGA2 (2001). Molecular evolutionary genetics analysis software, Bioinformatics, 17(12): 1244-1245.

Lau, M. C. Y.; Aitchison, J. C. and Pointing, S. B. (2009). Bacterial community composition in thermophilic microbial mats from five hot springs in central Tibet. Extremophiles, $13: 39-149$.

Lee, D.; Koh, Y.; Kim, K.; Kim, B.; Choi, H.; Kim, D. Suhartono, M. T. and Pyun, Y. (1999). Isolation and characterization of a Thermophilic Lipase From Bacillus Thermoleovorans ID-1. FEMS Microbiology Letters, 179 : 393-400.

Markossian, S.; Becker, P.; Mark1, H. and Antranikian, G. (2000). Isolation and Characterization of Lipid-Degrading Bacillus thermoleovorans IHI-91 from an Icelandic Hot Spring. Extremophiles, $4: 365-371$.

Maugeri, T. L.; Gugliandolo, C.; Caccamo, D. and Stackebrandt, E. (2001). A polyphasic taxonomic study of Thermophilic Bacilli from Shallow, Marine Vents. Systematic and Applied Microbiology, 24:572-587.

Mitchell, K. R. (2009). Controls on microbial community structure in thermal environments : Exploring bacterial diversity and the relative influence of geochemistry and geography. Dissertation Ph.D. Thesis University of New Mexico.

Podar, M. and Reysenbach, A. L. (2006). New opportunities revealed by biotechnological explorations of extremophiles. Current Opinion in Biotechnology, $17: 250-255$.

Reigstad, L. J.; Jorgensen, S. L. and Schleper, C. (2010). Diversity and abundance of Korarchaeota in terrestrial hot springs of Iceland and Kamchatka. International Society for Microbial Ecology, 4 : 346-356.

Rollof, J.; Hedstrom, S. A. and Nilsson-Ehle, P. (1987). Lipolytic activity of staphylococcus aureus strains from disseminated and localized infections. Acta Pathologica Microbiologica Scandinavica Series B : Microbiology, 95(1-6) : 109-113.

Sambrook, J. and Russell, D. W. (2001). Rapid isolation of yeast DNA. In : Molecular Cloning : A laboratory manual (eds. J. Sambrook and D W. Russell). Cold Spring Harbor Laboratory, New York, NY, USA, 2 : 631-632,

Satyanarayana, T.; Raghukumar, C. and Shivaji, S. (2005). Extremophilic microbes : Diversity and perspectives. Current Science, 89 : 78-90.

Sayeh, R.; Birrien, J. L.; Alain, K.; Barbier, G. and Hamdi, M. (2010). Microbial diversity in Tunisian geothermal springs as detected by molecular and culture-based approaches. Extremophiles, $14: 501-514$.

Sharma, A.; Pandey, A.; Shouche, Y. S.; Kumar, B. and Kulkarni, G. (2008). Characterization and identification of Geobacillus sp. isolated from Soldhar hot spring site of Garhwal Himalaya, India. Journal of Basic Microbiology, 48: 1-8.

Sharma, R.; Soni, S.; Vohra, R.; Gupta, L. and Gupta, J. (2002). Purification and characterization of a thermostable alkaline lipase from a new thermophilic Bacillus sp. RSJ-1. Process Biochemistry, 37: 1075-1084. 
Sinchaikul, S.; Sookkheo, B.; Phutrakul, S.; Pan, F. and Chen, S. (2001). Optimization of a Thermostable Lipase from Bacillus stearothermophilus P1 : Overexpression, Purification and Characterization. Protein Expression and Purification, 22:388-398.

Sievert, S. M.; Ziebis, W.; Kuever, J. and Sahm, K. (2000). Relative abundance of Archaea and Bacteria along a thermal gradient of a shallow water hydrothermal vent quantified by rRNA slot-blot hybridization. Microbiology, 146: 1287-1293.

Svendsen, A. (2000). Review - Lipase Protein Engineering. Biochimica et Biophysica Acta, 1543 : 223-238.

Tehei, M. and Zaccai, G. (2005). Adaptation to extreme environments : Macromolecular dynamics in complex systems. Biochimica et Biophysica Acta, 1724 : 404-410.

Thompson, J. D.; Higgins, D. G.; Gibson, T. J. and Clustal, W. (1994). Improving the sensitivity of progressive multiple sequence alignment through sequence weighting, position-specific gap penalties and weight matrix choice. Nucleic Acids Res., 22(22) : $4673-4680$.

Ugras, Serpil (2017), Characterization of a thermophilic lipase from Bacillus licheniformis ht7 isolated from Hayran thermal springs in giresun, Rom. Biotechnol. Lett., $22: 12297-12306$.

Verma, A.; Dhiman, K.; Gupta, M. and Shirkot, P. (2014). Bioprospecting of Thermotolerant Bacteria from hot water springs of Himachal Pradesh for the Production of Taq DNA Polymerase. Proceedings of the National Academy of Sciences, India Section B : Biological Sciences.

Zeikus, J. G.; Vieille, C. and Savchenko, A. (1998). Thermozymes : Biotechnology and structure - function relationship. Extremophiles, 2 : 179-183. 